NASA/TM-2005-213581

\title{
Intermediate Temperature Water Heat Pipe Tests
}

\author{
Angirasa Devarakonda \\ Sest, Inc., Middleburg Heights, Ohio \\ Daxi Xiong and Duane E. Beach \\ Glenn Research Center, Cleveland, Ohio
}


Since its founding, NASA has been dedicated to the advancement of aeronautics and space science. The NASA Scientific and Technical Information (STI) Program Office plays a key part in helping NASA maintain this important role.

The NASA STI Program Office is operated by Langley Research Center, the Lead Center for NASA's scientific and technical information. The NASA STI Program Office provides access to the NASA STI Database, the largest collection of aeronautical and space science STI in the world. The Program Office is also NASA's institutional mechanism for disseminating the results of its research and development activities. These results are published by NASA in the NASA STI Report Series, which includes the following report types:

- TECHNICAL PUBLICATION. Reports of completed research or a major significant phase of research that present the results of NASA programs and include extensive data or theoretical analysis. Includes compilations of significant scientific and technical data and information deemed to be of continuing reference value. NASA's counterpart of peerreviewed formal professional papers but has less stringent limitations on manuscript length and extent of graphic presentations.

- TECHNICAL MEMORANDUM. Scientific and technical findings that are preliminary or of specialized interest, e.g., quick release reports, working papers, and bibliographies that contain minimal annotation. Does not contain extensive analysis.

- CONTRACTOR REPORT. Scientific and technical findings by NASA-sponsored contractors and grantees.
- CONFERENCE PUBLICATION. Collected papers from scientific and technical conferences, symposia, seminars, or other meetings sponsored or cosponsored by NASA.

- SPECIAL PUBLICATION. Scientific, technical, or historical information from NASA programs, projects, and missions, often concerned with subjects having substantial public interest.

- TECHNICAL TRANSLATION. Englishlanguage translations of foreign scientific and technical material pertinent to NASA's mission.

Specialized services that complement the STI Program Office's diverse offerings include creating custom thesauri, building customized databases, organizing and publishing research results ... even providing videos.

For more information about the NASA STI Program Office, see the following:

- Access the NASA STI Program Home Page at http://www.sti.nasa.gov

- E-mail your question via the Internet to help@sti.nasa.gov

- Fax your question to the NASA Access Help Desk at 301-621-0134

- Telephone the NASA Access Help Desk at 301-621-0390

- Write to:

NASA Access Help Desk

NASA Center for AeroSpace Information 7121 Standard Drive

Hanover, MD 21076 
NASA/TM-2005-213581

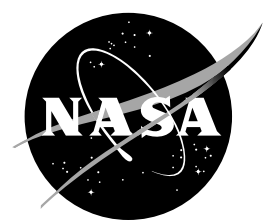

\title{
Intermediate Temperature Water Heat Pipe Tests
}

\author{
Angirasa Devarakonda \\ Sest, Inc., Middleburg Heights, Ohio \\ Daxi Xiong and Duane E. Beach \\ Glenn Research Center, Cleveland, Ohio
}

Prepared for the

Space Technology and Applications International Forum (STAIF-2005)

sponsored by the University of New Mexico's Institute for Space and Nuclear Power Studies (UNM-ISNPS)

Albuquerque, New Mexico, February 13-17, 2005

National Aeronautics and

Space Administration

Glenn Research Center 


\section{Acknowledgments}

This work was performed under NASA's Prometheus through Contract NAS3-03064 and carried out at NASA Glenn Research Center.

Available from

NASA Center for Aerospace Information 7121 Standard Drive

Hanover, MD 21076
National Technical Information Service 5285 Port Royal Road Springfield, VA 22100

Available electronically at http:/ /gltrs.grc.nasa.gov 


\title{
Intermediate Temperature Water Heat Pipe Tests
}

\author{
Angirasa Devarakonda \\ Sest, Inc. \\ Middleburg Heights, Ohio 44130 \\ Daxi Xiong* \\ National Aeronautics and Space Administration \\ Glenn Research Center \\ Cleveland, Ohio 44135 \\ Duane E. Beach \\ National Aeronautics and Space Administration \\ Cleveland, Ohio 44135
}

\begin{abstract}
Heat pipes are among the most promising technologies for space radiator systems. Water heat pipes are explored in the intermediate temperature range of 400 to above $500 \mathrm{~K}$. The thermodynamic and thermo-physical properties of water are reviewed in this temperature range. Test data are reported for a copper-water heat pipe. The heat pipe was tested under different orientations. Water heat pipes show promise in this temperature range. Fabrication and testing issues are being addressed.
\end{abstract}

\section{INTRODUCTION}

The National Aeronautics and Space Administration (NASA) is developing advanced space power conversion systems for deep space science missions. As part of the effort, the requisite radiator technologies for rejecting large amount of waste heat into space are also developed. To realize the objectives of higher efficiency and minimize the radiator area and mass, the heat rejection temperature range of $400-700 \mathrm{~K}$ is considered as an envelope.

Heat pipes are among the most promising technologies for space radiator systems. A heat pipe is a passive, twophase sealed device that rapidly transports large amount of heat with minimal temperature drop. The operational temperature range of the given application determines the type of heat pipe technology to be employed. The temperature range of $400-700 \mathrm{~K}$ is defined as intermediate for the purpose of heat pipe technology classification (Devarakonda and Olminsky, 2004).

Intermediate heat pipe technologies are much less developed compared to ambient and high temperature heat pipes. Above $700 \mathrm{~K}$, alkali metal heat pipes are in a mature stage of technology development. Ambient temperature heat pipe technologies (roughly 200 to $400 \mathrm{~K}$ ) have been quite advanced because of their wide ranging applications in commercial electronic cooling and others, with copper-water heat pipes being the most widely used. The recommended maximum temperature for water heat pipe operation is about $400 \mathrm{~K}$ because life test data are available only up to this temperature. While it is possible to use water as the heat pipe working fluid possibly up to $550 \mathrm{~K}$, test data have not been available at higher temperature range (Devarakonda and Olminsky, 2004).

NASA Glenn Research Center has been investigating many aspects of the intermediate heat pipe technology in relation to its application in the thermal management of advanced space power systems, in particular, radiators. The technology development is done in two directions. The first is the development of new heat pipe technologies for the temperature range considered. A number of potential heat pipe fluids are evaluated based on their thermo-physical properties. Thermo-chemical compatibility studies are currently carried out with potential envelope and wick materials (Devarakonda and Olminsky, 2004; Anderson et al., 2004; Devarakonda and Anderson, 2005).

Simultaneously, the use of water heat pipes for potential intermediate temperature operation is explored. The critical point of water is $647 \mathrm{~K}$. From thermodynamic property consideration, the rule of thumb for maximum heat pipe operational temperature is about $100 \mathrm{~K}$ below the critical temperature of its working fluid. Hence, it may be possible to utilize water heat pipes in the range of 400 to $550 \mathrm{~K}$, provided some technology issues are addressed.

*National Research Council-NASA Research Associate at Glenn Research Center 
Available copper-water heat pipe performance test data (Devarakonda and Olminsky, 2004) show that water heat pipes have a peak performance around $420 \mathrm{~K}$ and drops at temperatures higher than this; however, the heat pipes do perform well at higher temperatures. The peak performance temperature seems to be dependent only on the thermodynamic properties of water and not on other factors like the length and the diameter of the heat pipe, the wick structure or the metal properties. The drop in heat transfer rates at higher temperatures can be offset with larger diameter heat pipes. There is need for performance and life test data for water heat pipes in the temperature range of 400 to $550 \mathrm{~K}$. The water heat pipe test data available in literature are in the range of temperature below $400 \mathrm{~K}$, mostly geared toward electronic cooling applications within the ambient temperature heat pipe range, roughly defined as 200 to $400 \mathrm{~K}$. Test data have not been available in the intermediate temperature range, 400 to $700 \mathrm{~K}$. NASA Glenn Research Center has undertaken a testing program of water heat pipes in this latter temperature range.

\section{WATER PROPERTIES}

Water has the most desirable properties within the ambient temperature heat pipe range of about 300 to $400 \mathrm{~K}$ given by its vapor pressure and merit number. Its vapor pressure in this range is not too high compared to atmospheric pressure. However, at temperatures higher than $400 \mathrm{~K}$, its vapor pressure is much higher as shown in Fig. 1. With such high vapor pressures, the issues that need to be addressed are the increased thickness of the envelope to withstand this high pressure; and the necessity of strong braze/welds for the end-cap. Increased thickness has an advantage in protecting the heat pipe from possible micro-meteoroid impacts while the drawback is the added mass to the radiator system. These issues are particularly important for water heat pipes above $500 \mathrm{~K}$, because the vapor pressure in the heat pipe then would be more than about ten times atmospheric pressure.

Commercial copper-water heat pipes used in electronic cooling mostly sintered powder wicks. The heat pipe length varies between 6 in and 18 in depending on the applications. If the heat pipe is long $(\sim 1 \mathrm{~m})$, as is likely in space applications, the wick structure will be an important technology issue. It is difficult to sinter in a long pipe because of the associated problems with mandrel as well as potentially less structural strength in the wick.

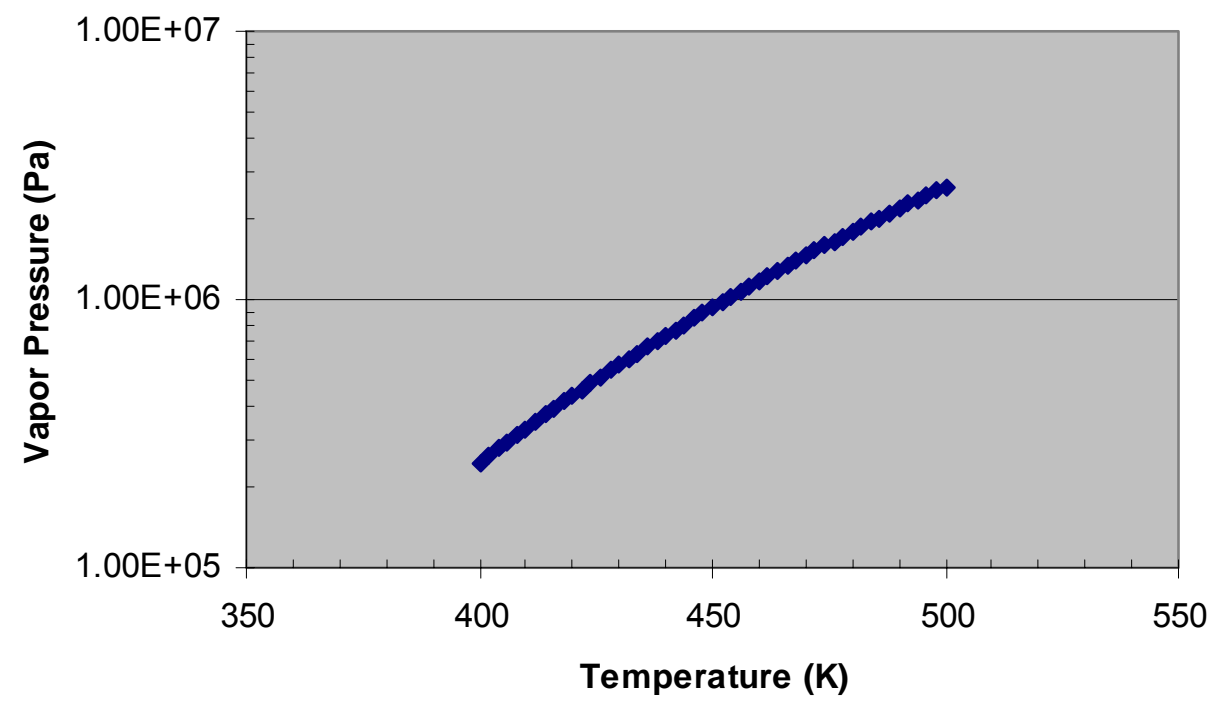

FIGURE 1. Vapor Pressure of Water within the Intermediate Temperature Range.

In the evaluation of potential heat pipe fluids, a useful merit number is defined based on the thermo-physical properties of the fluid (variously called the liquid transport factor and the figure of merit), $\mathrm{M}$, given by (Devarakonda and Anderson, 2005) 


$$
\mathrm{M}=\frac{\rho_{\mathrm{L}} \cdot \sigma \cdot \lambda}{\mu_{\mathrm{L}}}
$$

Figure 2 gives merit number data for water in the intermediate temperature range. Water has very high merit number (or liquid transport factor) until about $550 \mathrm{~K}$ and then drops off steeply. It appears then worthwhile to explore water as a potential heat pipe fluid up to $550 \mathrm{~K}$ by addressing the technology issues as discussed above. In addition, life test data at these higher temperatures need to verify that water is chemically stable, i.e., it does not dissociate or ionize. Long term high temperature thermo-chemical compatibility with envelope and wick metals also needs to be proven.

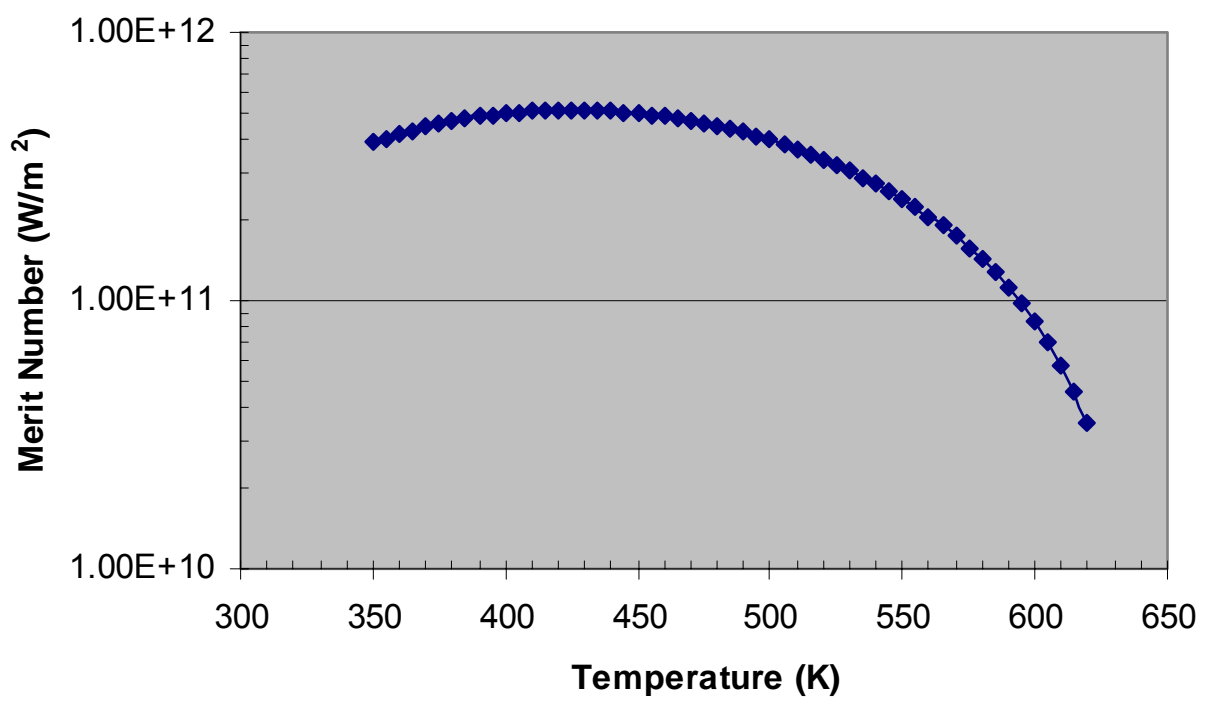

FIGURE 2. Merit Number (M) for Water as Intermediate Temperature Heat Pipe Fluid.

Water as a heat pipe fluid is known to be compatible with copper in electronic cooling applications. Titanium-water heat pipes have also been made and tested (Anderson et al., 2004). Titanium appears to be a good candidate metal for aerospace applications because of its many desirable properties, such are low density, high strength and conductivity.

\section{INTERMEDIATE TEMPERATURE WATER HEAT PIPE TESTS}

Commercial copper-water heat pipes are being tested at NASA Glenn Research Center above $400 \mathrm{~K}$ to demonstrate their intermediate temperature working capability. This paper reports the preliminary results. Since the heat pipe is a sealed device, no measurements can be made inside the pipe. The external testing of heat pipe is simple in conception. The evaporator region is heated, the condenser region is cooled, and the heat transfer rate and the temperatures at various axial locations on the surface of the heat pipe are measured.

The type of cooling employed at the condenser depends on the objective of the testing. If the maximum heat transfer capability of the heat pipe is to be determined, then the condenser region can be actively cooled by various means, for example, by providing fins and blowing air over them. In the current testing program, our goal is to stretch the maximum operational temperature of the water heat pipe beyond $400 \mathrm{~K}$. Hence the tests are conducted under ambient (room) conditions where the only mode of cooling the condenser region of the heat pipe is by natural convection and without any surface area enhancement (like fins).

Figure 3 shows a sketch of the experimental setup. The evaporator region of the heat pipe is inserted into a heater block. Thermal grease is used between the heater block and the cartridges and between the block and the heat pipe to improve thermal contact. The heater block is insulated well with insulation-tape. 
Six thermocouples are used to record the temperature along the heat pipe surface. A variable power transformer is used to control the temperature in the block by monitoring the three attached thermocouples. They should show essentially the same temperature. This factor is important to demonstrate that the heater block works has a lumped heat capacity system and has no internal temperature gradients. The heater temperature is taken to be the arithmetic average of the three temperatures.

A voltmeter and an ammeter were used to measure the voltage and the current, so that the power supplied to the heater could be calculated.

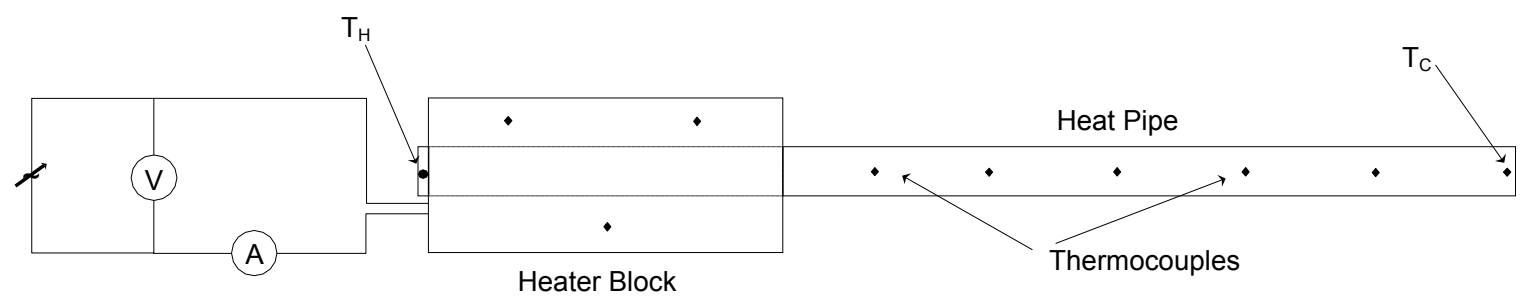

FIGURE 3. A Sketch of the Experimental Setup.

\section{Test Procedure and Results}

Test results are presented here for a copper-water heat pipe 1 in diameter and 6 in long. This heat pipe consists of a high performance sintered copper powder wick and a working fluid of de-ionized distilled water.

Electric power was supplied in increments of about $10 \mathrm{~W}$ through a cartridge heater inserted into the heater block. Measurements were recorded under steady-state conditions. The heat pipe was judged to be under steady-state operation if there was no change in its operational temperature in a fifteen minute time span.

The axial temperature drop $\left(\mathrm{T}_{\mathrm{H}}-\mathrm{T}_{\mathrm{C}}\right)$ from end to end of the heat pipe is less than $2{ }^{\circ} \mathrm{C}$ for all data measured; in most cases it is $\sim 1^{0} \mathrm{C}$. The five thermocouples placed along the length of the heat pipe on its surface (Fig. 3) essentially showed the same temperature. The operational temperature is taken to be the arithmetic average of these five thermocouple measurements. Power supplied to the evaporator is calculated as the product of the heater cartridge voltage and the current (voltmeter and ammeter readings).

Figure 4 shows the operational temperature for the heat pipe under different orientations. The condenser end of the heat pipe is above the evaporator in the gravity aiding (g-aiding) orientation and the evaporator is above in the gopposing orientation. The heat pipe continues to perform well beyond an operational temperature of $450 \mathrm{~K}$ in all orientations. The orientation does not have a significant impact on the heat pipe performance under natural convection cooling. The heat transfer continues to improve/increase with the increase in operational temperature.

In horizontal orientation, the heat pipe is tested under much higher temperature as shown in Fig. 5. The heat pipe continued to perform even above $500 \mathrm{~K}$ without any drop in performance under natural convection conditions. The heat pipe tested was not manufactured to withstand much higher pressures than this and hence it was not possible to test at higher temperatures. Additional testing with structurally stronger copper-water and titanium-water heat pipes will be undertaken at NASA Glenn Research Center.

As pointed out above, this test was not designed for measuring the maximum possible heat transfer at the given temperature. For that purpose, the condenser region needs to be equipped with various ways of cooling (or heating to a temperature just below the temperature of the evaporator). The heat transfer rate depends on the ambient conditions (i.e., the cooling of the condenser region) prevalent in a given application. Hence separate and elaborate test procedures need to be designed for that purpose. In the present testing, our goal is to determine experimentally the upper operational temperature limits of a copper-water heat pipe. 


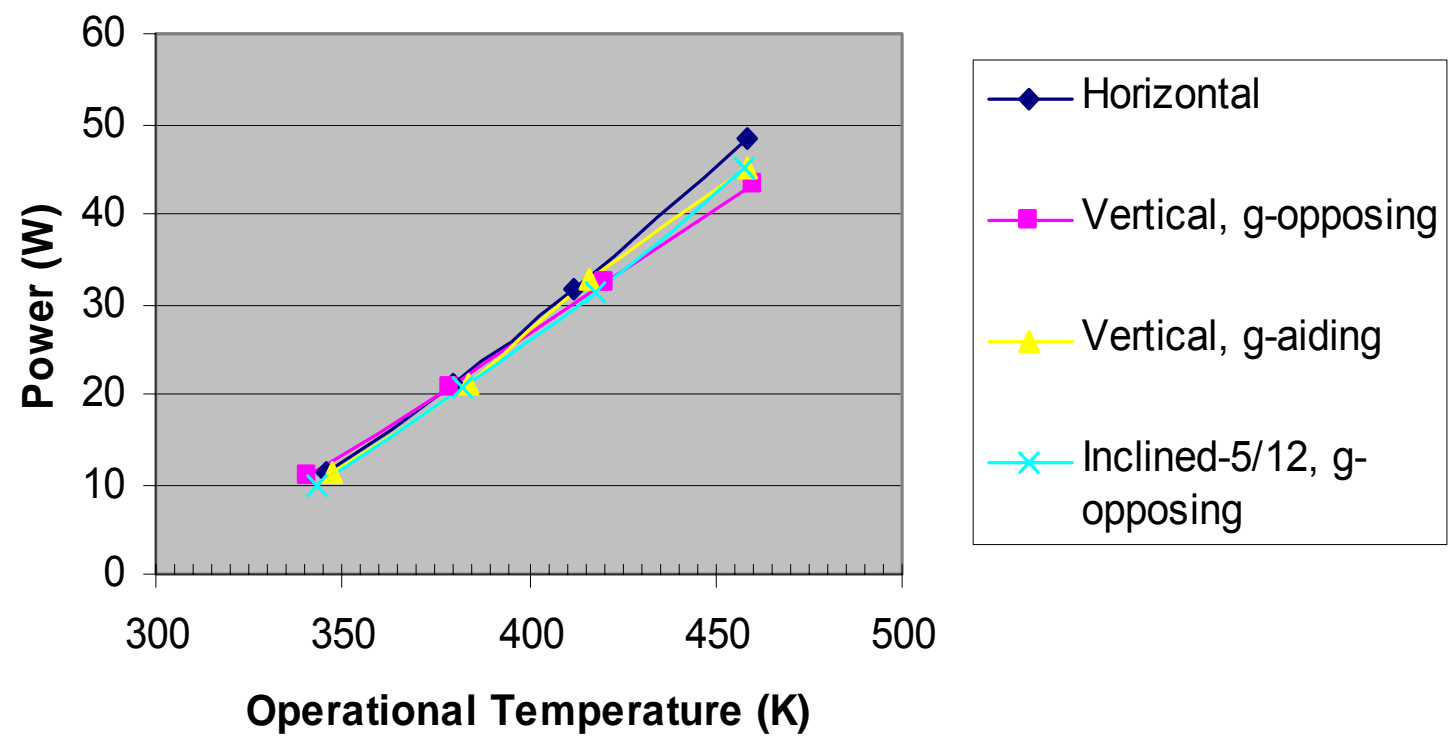

FIGURE 4. Operational Temperature of Water Heat Pipe with Various Orientations.

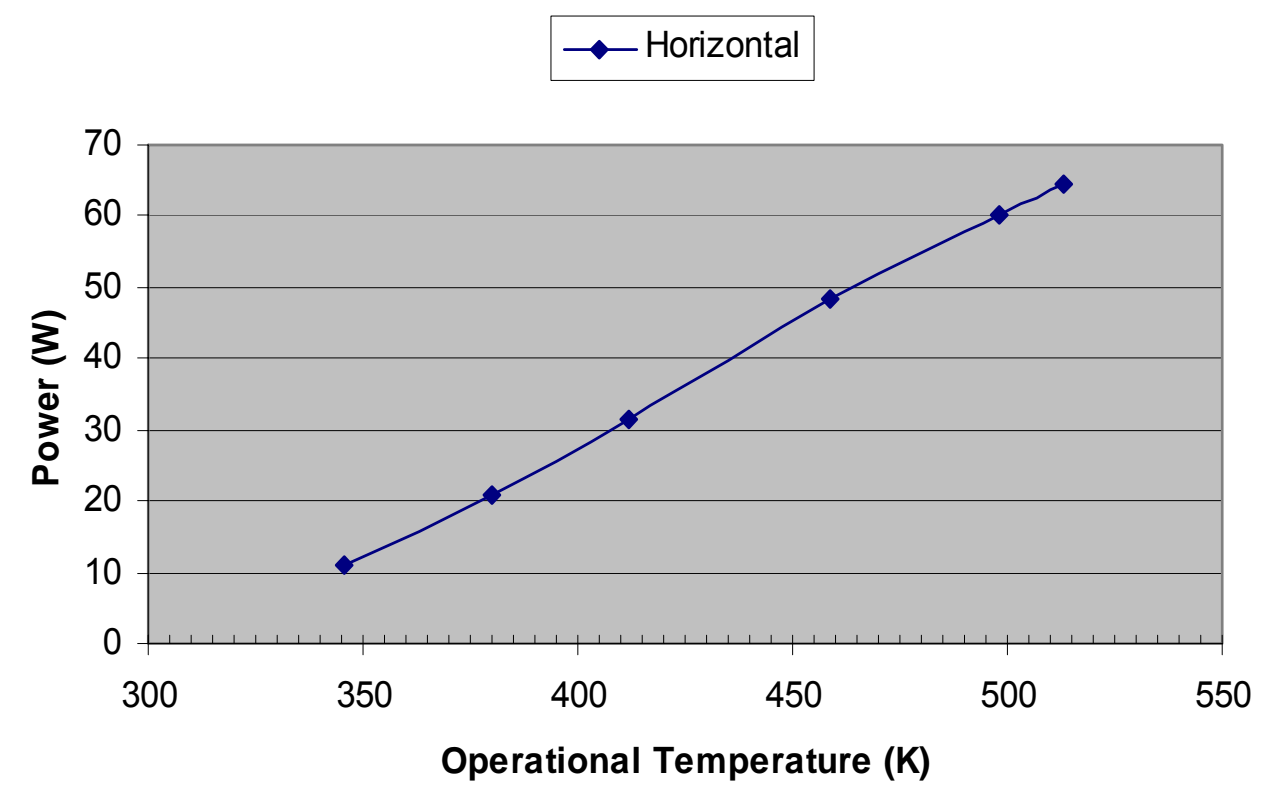

FIGURE 5. Higher Operational Temperature (> 500 K) Tested Under Horizontal Orientation. 
From the measurements we have so far made, it looks feasible to extend the operational temperature range of water heat pipes above $500 \mathrm{~K}$. The associated fabrication and testing issues are currently being addressed.

\section{CONCLUSIONS}

Water heat pipes are considered as intermediate temperature (400 to $700 \mathrm{~K}$ ) heat pipes for space thermal management applications. Available test data are within the ambient temperature range typical of terrestrial electronic cooling applications. This paper reported experimental data of a copper-water heat pipe under different orientations at higher temperatures, 350 to above $520 \mathrm{~K}$. Nearly identical high thermal performances were realized in all orientations with reference to gravity. Water heat pipes are promising at temperatures above $500 \mathrm{~K}$. Vapor pressure of water at these temperatures is rather high and fabrication technology and testing conditions are some of the issues that need to be addressed.

\section{NOMENCLATURE}

$\mathrm{M}=$ merit number, or liquid transport factor $\left(\mathrm{W} / \mathrm{m}^{2}\right)$

$\mathrm{T}_{\mathrm{C}}=$ heat pipe condenser temperature

$\mathrm{T}_{\mathrm{H}}=$ heat pipe evaporator temperature

$\lambda=$ latent heat of evaporation $(\mathrm{J} / \mathrm{kg})$

$\mu_{\mathrm{L}}=$ viscosity of liquid $(\mathrm{kg} / \mathrm{m} \mathrm{s})$

$\rho_{\mathrm{L}}=$ density of liquid $\left(\mathrm{kg} / \mathrm{m}^{3}\right)$

$\sigma=$ surface tension $(\mathrm{N} / \mathrm{m})$

\section{REFERENCES}

Anderson, W. G., Rosenfeld, J. H., Angirasa, D., and Me, Y., "Evaluation of Heat Pipe Working Fluids in the Temperature Range 450 to 700 K,” Proceedings of the Space Technology \& Applications International Forum (STAIF-2004), 2004.

Devarakonda, A., and Olminsky, J. K., "An Evaluation of Halides and Other Substances as Potential Heat Pipe Fluids," Proceedings of the $2^{\text {nd }}$ International Energy Conversion Engineering Conference (IECEC), 2004.

Devarakonda, A., and Anderson, W. M., “Thermo-Physical Properties of Intermediate Temperature Heat Pipe Fluids”, in these Proceedings of the Space Technology \& Applications International Forum (STAIF-2005), 2005. 


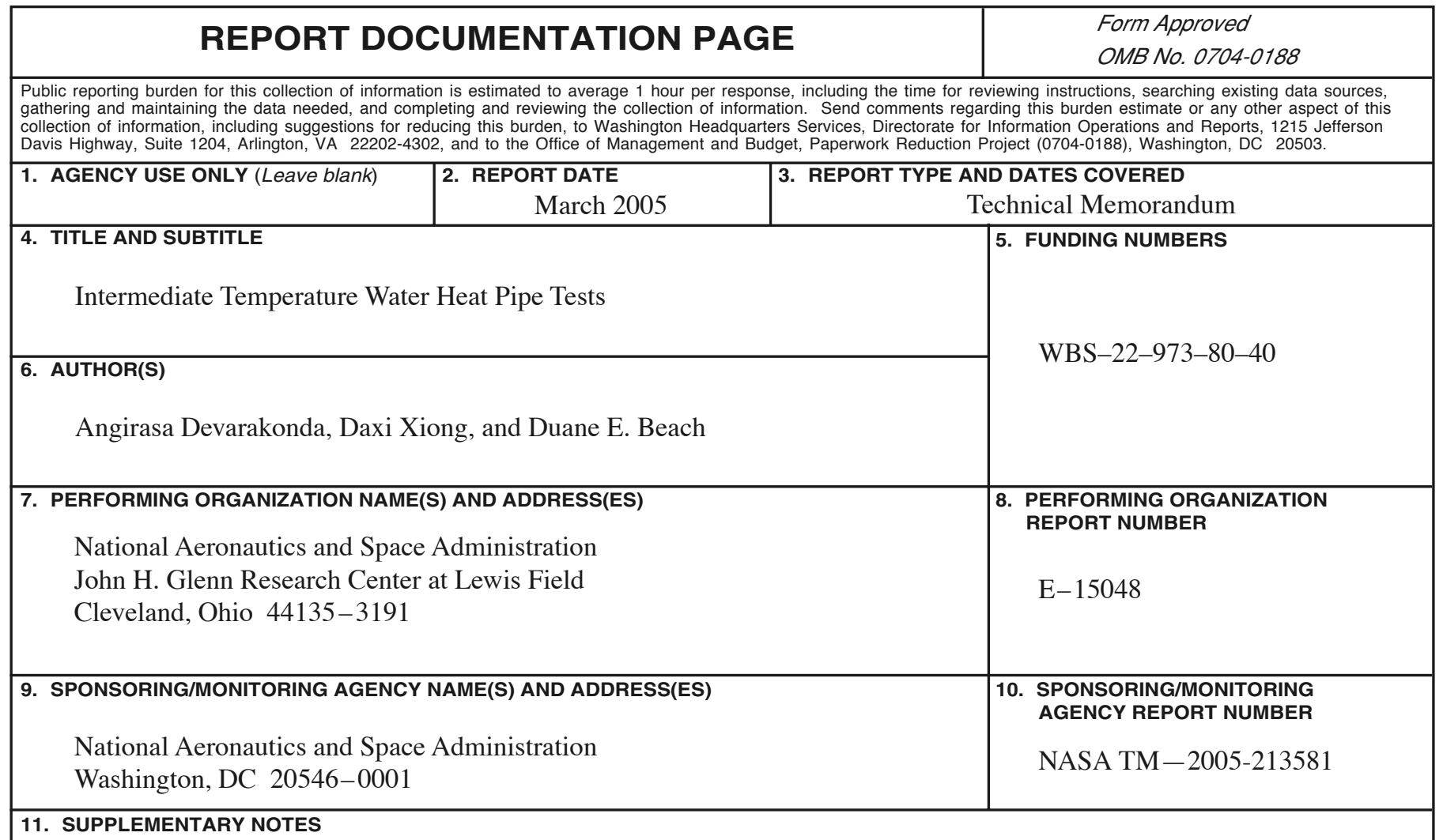

Prepared for the Space Technology and Applications International Forum (STAIF-2005) sponsored by the University of New Mexico's Institute for Space and Nuclear Power Studies (UNM-ISNPS), Albuquerque, New Mexico, February 13-17, 2005. Angirasa Devarakonda, Sest, Inc., 18000 Jefferson Park, Suite 104, Middleburg Heights, Ohio 44130 e-mail: Angirasa Devarakonda@grc.nasa.gov, 216-433-3914; Daxi Xiong, National Research Council-National Research Associate at Glenn Research Center; and Duane E. Beach, NASA Glenn Research Center. Responsible person, Angirasa Devarakonda, organization code RPT, 216-433-3914.

\begin{tabular}{|l|l|l}
\hline 12a. DISTRIBUTION/AVAILABILITY STATEMENT & 12b. DISTRIBUTION CODE
\end{tabular}

Unclassified - Unlimited

Subject Category: 20

Available electronically at http://gltrs.grc.nasa.gov

This publication is available from the NASA Center for AeroSpace Information, 301-621-0390.

13. ABSTRACT (Maximum 200 words)

Heat pipes are among the most promising technologies for space radiator systems. Water heat pipes are explored in the intermediate temperature range of 400 to above $500 \mathrm{~K}$. The thermodynamic and thermo-physical properties of water are reviewed in this temperature range. Test data are reported for a copper-water heat pipe. The heat pipe was tested under different orientations. Water heat pipes show promise in this temperature range. Fabrication and testing issues are being addressed.

\begin{tabular}{|c|c|c|c|}
\hline 14. SUBJECT TERMS & \multicolumn{2}{|c|}{ Heat pipes } & $\begin{array}{c}\text { 15. NUMBER OF PAGES } \\
12 \\
\end{array}$ \\
\hline
\end{tabular}



